\title{
Pengelolaan Keuangan Keluarga Dan Pengenalan Dasar-Dasar Investasi Menuju Keluarga Mandiri Bagi Ibu-Ibu Majlis Taklim Al Auladiyah Di Kelurahan Bakti Jaya Kecamatan Setu Tangerang Selatan
}

\author{
Endah Finatariani ${ }^{1}$, Setianingsih ${ }^{2}$, Anisa $^{3}$, Tsarina Zenabia ${ }^{4}$, Tubagus Arya Abdurachman ${ }^{5}$, \\ a,b,c,d,eProdi S1 Akuntansi, Fakultas Ekonomi, Universitas Pamulang* \\ Email : * tsarinazenabia89@gmail.com
}

\begin{abstract}
Abstrak
Kegiatan pengabdian Kepada Masyarakat yang telah berlangsung dari tanggal 6-8 Juli 2020 adalah untuk melaksanakan salah satu Tri Darma Perguruan Tinggi pada Universitas Pamulang dimana para dosen beraktifitas. Tujuan dari kegiatan PKM adalah untuk memperkenalkan Dasar-Dasar Investasi dan Manajemen Keuangan Menuju Keluarga Mandiri Pada Ibu-Ibu Majelis Taklim Al Auladiyah, Tangerang Selatan. Perencanaan keuangan keluarga dibutuhkan agar tujuan pengelolaan keuangan keluarga dapat tercapai secara efektif, efisien dan bermanfaat. Hal pertama yang harus difahami adalah kenali kondisi keuangan, tentukan kebutuhan utama bukan keinginan, tentukan prioritas dari kebutuhan-kebutuhan hindari keinginan yang tidak perlu dan jangan sampai "Besar Pasak Daripada Tiang". Salah satu tahapan perencanaan dalam keluarga adalah menyusun anggaran rumah tangga sehingga mencegah kegagalan keuangan dalam rumah tangga. Hasil akhir atau luaran dari kegiatan ini adalah meningkatkan pengetahuan pentingnya pemahaman, pengaturan keuangan, meningkatkan kesejahteraan keluarga sehingga terhindar dari ketergantungan meminjam uang pada kreditur
\end{abstract}

Kata-kata kunci: Perencanaan Keuangan, Kebutuhan Keluarga, Perencanaan Anggaran

\footnotetext{
Abstract

Pengabdian Kepada Masyarakat (PKM) which is called Community Service Activities was held from 6-8 July 2020 as a form to fulfilling the obligations of the higher education of Tri Dharma at Pamulang University. The purpose of this PKM is to Introduce Fundamental Investment and Financial Management Towards Independent Family For Majelis Taklim Al Auladiyah in Tangerang Selatan. Financial management for the family is needed so, therefore, all family needs such as food, clothes, shelter, school fee, or desire to buy a new motorbike/car can be fulfilled. First things first are getting to know your financial condition, and determine your needs not to wants, and choose top priority, the family has to prepare a household budget for current and future needs avoids unnecessary desires, and don't "Big Pegs than the Pole" neither. One of the stages of financial family planning is preparing a household budget to prevent financial failure in the household. The result or output of this activity is to increase knowledge of the importance of understanding, financial arrangements, improve family welfare to avoid dependence on borrowing money from creditors.
}

Keywords: Financial Management, Family Needs, Preparing Bugdet 


\section{PENDAHULUAN}

Penghasilan perlu dikelola agar dapat memenuhi kebutuhan saat ini dan juga kebutuhan di masa depan. Kebutuhan saat ini terdiri atas pengeluaran- pengeluaran yang dikeluarkan saat ini, sedangkan kebutuhan di masa depan terdiri atas pengeluaranpengeluaran di masa mendatang.

Setiap manusia memiliki risiko, risiko tersebut dapat mengganggu perolehan penghasilan saat ini dan di masa depan. Oleh karena itu perencanaan keuangan perlu dilakukan secepatnya agar kebutuhan di saat ini dan kebutuhan masa depan tetap dapat terpenuhi. Menurut Ahmad Gozali (2009) kiat dan tips rahasia sukses dalam mengatur keuangan keluarganya dapat ditempuh dengan langkah-langkah sebagai berikut, yaitu:

Utamakan yang utama maksudnya hal ini terkait dengan kewajiban, jika keluarga memiliki hutang/ pinjaman maka terlebih dahulu adalah menyisihkan penghasilan untuk membayar hutang atau pinjaman; selanjutnya yang dilakukan adalah berzakat atau memberikan sumbangan keagamaan, sebagai salah satu bukti rasa syukur kita kepada Allah SWT, Dialah yang telah memberikan karunia rezeki kepada kita semua, sehingga kita bisa melakukan aktivitas ekonomi keseharian dengan lancar tanpa kekurangan, dengan berzakat akan semakin menambah karunia dan rezeki yang berlimpah kepada kita; yang paling penting adalah menyisihkan minimal $10 \%$ penghasilan untuk ditabung/investasi; kemudian ketika semua langkah-langkah tersebut diatas terpenuhi maka sisa penghasilan dapat digunakan untuk keperluan rutin harian seperti belanja isi dapur, makan, lauk-pauk, asuransi, sekolah anak, rekreasi, beli baju dan sebagainya.

Di dalam buku Perencanaan Keuangan yang dikeluarkan oleh Otoritas Jasa Keuangan (OJK:08) dijelaskan pula bagaimana cara merencanakan keuangan yang baik, Berikut langkah- langkah yang diperlukan untuk merencanakan keuangan:

1. Kenali Kondisi Keuangan

2. Tentukan Keinginan

3. Tentukan Keinginan Utama kita tidak bisa memenuhi seluruh keinginan tersebut karena adanya keterbatasan. Salah satu keterbatasan yang dimiliki adalah kemampuan keuangan. Oleh karenanya kita perlu membuat urutan keinginan mana yang harus didahulukan.

- Salah satu tahapan dalam perencanaan keuangan yang cukup penting adalah penyusunan anggaran rumah tangga, karena 
di tahap ini merupakan inti mengelola uang yang kita peroleh untuk mencukupi kebutuhan saat ini dan kebutuhan di masa depan. Anggaran yang sehat adalah ketika jumlah pemasukan sama atau lebih besar dari pada pengeluaran, jangan sampai pengeluaran kita lebih besar dari pada pemasukan kita yang sehingga akan menyebabkan kondisi keuangan menjadi defisit.

Kesadaran untuk berinvestasi sangat dibutuhkan, melalui edukasi berinvestasi masyarakat bukan hanya dapat merencanakan keuangan keluarga tapi juga mampu mengelola dengan baik, menurut Downes dan Goodman 2001: 1, investasi pada hakekatnya merupakan penempatan sejumlah dana pada saat ini dengan harapan untuk memperoleh keuntungan di masa yang akan datang. Ada dua faktor yang dipertimbangkan dalam pangambilan keputusan, yaitu tingkat pengembalian dan risiko. Selanjutnya ada 5 faktor yang mempengaruhi pilihan dalam berinvestasi yaitua:

1. Keamanan dan risiko (keamanan dalam suatu investasi berarti risiko kerugian minimal)

2. Komponen faktor risiko (komponen faktor risiko yang berkaitan dengan investasi khusus berubah dari waktu ke waktu),
3. Pendapatan investasi (pendapatan dalam bentuk tunai dan bersifat pasti)

4. Pertumbuhan investasi (peningkatan dalam nilai, seperti saham)

5. Likuiditas (tinggi atau rendah).

Pada era digital saat ini investor dalam hal ini keluarga dapat dengan mudah memilih instrumen investasinya melalui aplikasi ataupun platform investasi, dengan modal kecil sekali pun. Namun, tetap harus memiliki sikap kehati-hatian dalam memilih instrumen dan platform yang tepat untuk berinvestasi.

Tujuan dan target yang ingin dicapai dalam kegiatan pengabdian kepada masyarakat ini adalah pelaksanaan perencanaan keuangan rumah tangga sehingga dapat mencegah kegagalan keuangan dalam rumah tangga. Luaran yang dihasilkan adalah menumbuhkan pengelolaan keuangan yang baik dalam rumah tangga sehingga terhindar dari ketergantungan dari berhutang atau meminjam dari lembaga pembiayaan.

\section{METODE}

Kegiatan Pengabdian Kepada Masyarakat (PKM) bertempat di Mesjid Al Auladiyah, Kelurahan Bakti Jaya, Kecamatan Setu, Kota Tangerang Selatan, tanggal 6-8 Juli 2020, pukul 09.00 WIB s/d 12.00 WIB. Kegiatan PKM kali ini menyasar ibu-ibu Majelis 
Taklim Al-Auladiyah. Majelis Taklim sudah ada sejak zaman Rasulullah SAW, saat ini Majelis Taklim sudah tidak asing lagi bagi masyarakat karena fungsi nya sebagai tempat belajar-mengajar dan wadah berkreasi serta pusat pembinaan dan pengembangan pendidikan dan ketrampilan (Muhsin MK, 2012). metode kegiatan menggunakan metode ceramah di mana peserta diberikan pemahaman dan gambaran umum pentingnya perencanaan keuangan secara sederhana yang dapat diaplikasikan dalam keuangan keluarga; metode tutorial disini peserta diberikan beberapa contoh pengelolaan keuangan keluarga secara manual dengan menggunakan aplikasi di smartphone; dan metode diskusi bagian peserta dapat mengkomunikasikan terkait kondisi keuangan dan kendala yang sering dialami oleh peserta. Permasalahan dan kondisi ekonomi masing-masing keluarga berbeda, sehingga perlu ditelaah dan ditindaklanjuti pengelolaan keuangannya dengan penyesuaian dari kondisi keuangan masing masing.

\section{HASIL DAN PEMBAHASAN}

Tujuan kegiatan ini adalah untuk memberikan penyuluhan kepada ibu-ibu majelis taklim yang notabene adalah ibu rumah tangga dalam mengelola keuangan dan pengenalan dasar-dasar investasi, bagaimana berinvestasi secara cerdas dan aman dengan memanfaatkan sumber daya terbatas yang dimiliki dan mengelolanya dengan optimal. Kegiatan penyuluhan ini diikuti kurang lebih 35 peserta yang terdiri ibu-ibu majlis taklim, pengurus masjid dan perwakilan mahasiswa serta panitia pelaksana yang merupakan dosen Universitas Pamulang.

Peserta mengikuti pemaparan dari pemateri dengan seksama dan terlihat antusias saat sesi tanya jawab dengan peserta yang memanfaatkan momen untuk bertanya, di antaranya meminta pendapat mengenai bagaimana mengelola keuangan dengan dana yang terbatas, kemudian investasi apa yang tepat yang dapat dilakukan dengan aman dan dengan keterbatasan dana bagi ibu rumah tangga.

Dibutuhkan kesadaran akan perlunya hidup hemat, membuat skala prioritas dan memanfaatkan dana lebih belanja untuk berinvestasi, mengelola keuangan sebaik mungkin dalam rangka perencanaan keuangan dimasa mendatang, seperti rencana pendidikan anak, pernikahan, renovasi rumah, membeli kendaraan dan sebaginya.

Tips dasar pengelolaan keuangan keluarga yang diberikan kepada peserta penyuluhan diantaranya sebagai berikut: 
1. Mengetahui besaran pendapatan setiap periode (biasanya setiap bulan).

2. Skala Prioritas, menentukan pengeluaran mana yang lebih penting dalam waktu dekat.

3. Mencatat pengeluaran dan pemasukan setiap hari, dibuatkan anggaran pengeluarani. Sisa lebih harian yang bisa di tabung atau untuk investasi.

4. Evaluasi, dengan membuat pembukuan sederhana akan memberikan pengetahuan di sisi mana pengeluaranpengeluaran yang dapat dihemat, dan sisi pendapatan untuk berinvestasi.

Investasi merupakan pengorbanan yang dilakukan pada saat sekarang dengan tujuan untuk mendapatkan manfaat yang lebih besar di masa yang akan datang. (Putri, 2017). Pilihan investasi yang disarankan kepada peserta penyuluhan adalah dengan cara: menabung, deposito, membeli emas ataupun reksadana.

\section{KESIMPULAN}

Kegiatan PKM kali ini menghasilkan kesimpulan bahwa Ibu-Ibu Majlis Taklim Al Auladiyah, Bakti Jaya, Setu, Kota Tangerang Selatan cukup tinggi kesadaran dalam berinvestasinya, hal ini dapat dilihat dari semangat dan pertanyaan-pertanyaan yang diutarakan saat sesi tanya jawab. Namun masih perlu ditumbuhkembangkan lagi agar dapat memilih dan melakukan investasi dengan aman dan hasil yang maksimal untuk dapat mempersiapkan kebutuhan keuangan jangka pendek maupun jangka panjang dan akhirnya mencapai keluarga yang sejahtera.

Selain itu, kebanyakan dari ibu-ibu majlis taklim tersebut juga mempunyai usaha sampingan seperti berjualan, meliliki toko kelontong, berjualan online dengan sistem dropship, berjualan kue dan sebaginya, dalam rangka membantu perekonomian keluarga.

Peserta diberikan bimbingan bagaimana cara mengelola keuangan, agar sebagian dari hasil usaha sampingannya dapat ditabung atau diinvestasikan untuk kebutuhan keuangan di masa mendatang.

PKM yang dilaksanakan merupakan kerjasama dosen prodi S1 Akuntansi Universitas Pamulang dengan pengurus masjid Al Auladiyah, Kelurahan Bakti Jaya, Kecamatan Setu, Kota Tangerang Selatan ini memang dilaksanakan dengan masih banyak kekurangan dan keterbatasan, kami menyarankan untuk PKM selanjutnya, pengenalan dasar-dasar inverstasi ini melibatkan tidak hanya ibu-ibu rumah tangga melainkan juga bapak-bapak sebagai kepala keluarga serta melibatkan institusi dari pasar modal secara langsung dalam kegiatan penyuluhan, agar peserta dapat memperoleh 
gambaran lebih baik lagi mengenai investasi saham maupun reksadana.

\section{UCAPAN TERIMAKASIH}

Dengan memanjatkan puji dan syukur kehadirat Illahi atas terselenggaranya kegiatan PKM di Majelis Taklim Al Auladiyah, tak lupa

\section{REFERENSI}

Garlans, S.N. (2014). Motivasi Sebagai Penentu Perencanaan Keuangan. Jurnal Ilmiah Akuntansi dan Bisnis, Vol. 9, No.1:42-48

https://sikapiuangmu.ojk.go.id/FrontEnd/ima ges/FileDownload/25_Buku_Perencan aan_Keuangan.pdf

https://sikapiuangmu.ojk.go.id/FrontEnd/CM S/DetailMateri/17

Koordinator Dakwah Islam. (1986). hal. 65. Muhsin MK, ibid, hal. 9-12. Website:http://uchinfamiliar.blogspot.c om/2009/02/pengertian-majelis-taklimdasar-hukum.html, 8 April 2012.

Muhsin MK, ibid, hal. 6, ia mengutip dari Mohammad Ali Al-Hasyimi, Kepribadian wanita muslimah, hal. 256. ibid, penulis mengutip dari, AM Saefudin, Ada Hari Esok, hal. 34-35. Ibid, hal. 7, penulis mengutip dari Dakwah Menjelang Tahun, Jakarta:

Pangeran, Perminas. (2012). Sikap Keuangan Rumah Tangga Desa pada Aspek Perencanaan Keuangan. JRAK, Vol.8, No.1:35-50

Putri, N. M. D., \& Rahyuda, H.. (2017). Pengaruh Tingkat Financial Literacy Dan Faktor Sosiodemografi Terhadap kami mengucapkan banyak terimakasih kepada seluruh Jemaah Masjid Al Auladiyah serta Bapak H. Basuki Boa, Pimpinan Ketua DKM Al Auladiyah, Baktijaya-Setu, Pocis - Tangerang Selatan.

Perilaku Keputusan Investasi Individu. E-Jurnal Ekonomi dan Bisnis Universitas Udayana, 6(9).

Setiawan, B. J. J. A. M. (2018). Edukasi Literasi Keuangan Pasar Modal Pengurus PKK Kecamatan Sako Palembang. 2(1).

Silvy, M., \& Yulianti, N. (2013). Sikap pengelola keuangan dan perilaku perencanaan investasi keluarga di Surabaya. Journal of Business \& Banking (JBB), 3(1), 57-68. Tangsel, B. P. S. K. (2019). Kecamatan Setu Dalam Angka 2019.

Subaida, Ida. (2019). Pelatihan Manajemen Kas Rumah Tangga Untuk Mencegah Kegagalan Keuangan Rumah Tangga (Family Financial Distress). INTEGRITAS : JurnalPengabdian Vol 3, No 1. ISSN 2580-7978 (Cetak) ISSN 2615-0794 (Online). 